\title{
The Complexity integrated-Instruments components media of IPA at Elementary School
}

\author{
Siska Angreni, ${ }^{*}$, and Rona Taula Sari \\ ${ }^{1}$ FKIP, Univrsitas Bung Hatta, 21571 Padang, Indonesia
}

\begin{abstract}
This research aims at describing the complexity of Integrated Instrument Components media (CII) in learning of science at Elementary schools in District Siulak Mukai and at Elementary schools in District Siulak. The research applied a descriptive method which included survey forms. Instruments used were observation sheets. The result of the research showed Integrated Instrument Components media (CII) natural science that complexity at primary school district Siulak was more complex compared with that at primary school district Siulak Mukai. is better than from primary school district Mukai
\end{abstract}

\section{Introduction}

Increasing quality of education is the need of the nation that wants to move forward.With confidence, that quality education can support the development in every sector. Hence, education needs to be most attended so we can catch up in science and technology from another country .One government efforts to improve the quality of education is with a procurement program and infrastructure in education. Provision of infrastructure is intended to support the process and improve learning outcomes of students all levels (primary school, junior high school and senior high school) (Maryandi, 2013). As provision and infrastructure from the government for each school is learning media or the learning tools .Besides junior and senior high school, primary school also received assistance on learning media from the government.

One of the media given by the government is Integrated Instrument Components media (CII) for science. Integrated Instrument Components media (CII) for science provides a pleasant learning on the subjects of science which has perfect adjusted to the curriculum. Every elementary school has Integrated Instrument Components media (CII) provided by the goverment as well as possible in learning. Schools that have Integrated Instrument Components media (CII) should keep and use the media full. With the Integrated Instrument Components media (CII) for science expected to improve achievement and learning outcomes students. Learning of media actually hold a very important role, especially for teaching science. Many the concept of science are very abstract to measure at the primary school, so the concept of this kind of teaching needs to be adequately supported by media. The result of study also found that learning using teaching media will increase the quality of learning. Based on the research done by Maryandi ( 2013 ) the utilization of science media kit exerts positive on students study results. While the results of Angreni research shows ( 2017 ) that the availability of CII media science in primary schools in Nanggalo allow for learning to use the media but its use is not yet full.

Based on preliminary observations in several public primary schools district Siulak Mukai and public primary schools district Siulak .The elementary school in observation in kecamatan siulak mukai namely, of public elementary school 062 /III Mukai Mudik, of public elementary school 169 /III Mukai Mudik, of public elementary school 122 /III

* Corresponding author: siskaangrenisiska@gmail.com 
Mukai Tengah .While observation in kecamatan siulak namely of public elementary school 114/III Desa Baru Siulak , of public elementary school 044/III Siulak Gedang, of public elementary school 041 /III koto Beringin, a means of learning at the school is not complete especially for learning science lessons .For example in public primary schools 169 / III Mukai Mudik, amous 10 integrated instrument components media (CII) for science that is observed only 5 integrated instrument components media (CII) were, but not complete. It was because the arrangement integrated instrument components media (CII) for science often chauded .In addition, the school had experienced fire so many facilities and infrastructure burned including integrated instrument components media (CII) for science. Next in public primary schools 122/III Mukai Tengah and public primary schools 062 /III Mukai Mudik, of 2 schools they only found 6 integrated instrument components media (CII) for science but that they are incomplete for example kit electricity there is just cable and the battery missing, then integrated instrument components astronomy only the solar system them just, planets has been no longer .One of the causes of the lack of integrated instrument components media (CII) for science a place arrangement and inadequate care.

School as a recipient integrated instrument components media (CII) for science were supposed to provide a depository properly so as not to broken and eaten by rats .In addition , teachers were supposed to make use of an integrated instrument components media (CII) for science as maximum as possible so that the supply of and the condition of the media an integrated instrument components media (CII) for science always be monitored well .By using an integrated instrument components media (CII) for science learning is fun and students learning outcomes would rise .Based on fact that were found in the field the availability of media kits ipa in public primary schools district Siulak Mukai and public primary schools district Siulak needs to be reconsidered.

As for the purpose of this research is to describe the availability of and complexity of integrated instrument components media (CII) for science in public primary schools Siulak Mukai and Siulak. According to winanto (2011) integrated instrument components media (CII) for science is an apparatus used as an intermediary to explain concepts of science delivered by teachers. Next according to Umra Hi (2013) integrated instrument components media (CII) for science is media used in proving theories ipa associated with the natural environment in which the object get students to be able to develop their potential. According to Smaldino in Anitah (2009) CII is box equipment as a collection of materials that contains more than one kind of props in organize to one particular subject.

\section{Method}

According to sugiyono in 2008, research methodology is interpreted as a scientific way to get data with purpose and specific use.In accordance with the issues to be examined so method to be used in research is the method descriptive. Method according to Sukmadinata (2011) descriptive research is a form of research describing the facts, good phenomenon which is natural or engineered by man. This study aims to to describe the state of real its about completenessis integrated instrument components media (CII) for science in public primary schools sub district Siulak Mukai and public primary schools sub district Siulak. This research used the kind of research survey. Population in this research is public primary schools which below the uptd Siulak Mukai and uptd Siulak which consisted of 30. Even though they were divided into two district but the uptd Siulak Mukai with Siulak still joined , the uptd office is located in kecamatan siulak. While sample in this research was 12 public primary schools.

Research locations are 12 public primary schools in kecamatan siulak and kecamatan siulak mukai kabupaten kerinci .Research locations in Siulak disric there are 6 public primary schools among other: public primary schools 114/III desa baru siulak, public primary 
schools 044/III siulak gedang, public primary schools 123/III Dusun Dalam, public primary schools 075/III Koto Rendah, public primary schools 088/III Siulak Panjang, public primary schools 041/III Koto Beringin. While in Siulak Mukai district there were 6 of public school among other: public primary schools 062/III Mukai Mudik, public primary schools 078/III Mukai Hilir, public primary schools 122/III Mukai Tengah, public primary schools 077/III Mukai Tinggi, public primary schools 169/III Mukai Mudik, public primary schools 216/III Sungai Langkap. The choice of research location was due to the fact that it the observation has been done about integrated instrument components media (CII) in some public in district Siulak and Siulak Mukai.

Techniques used to collect the data in this research were: (1) a direct observation, according to (Hadari Nawawi in 2007), observation directly is the method for data collection done through the observation and recording symptoms looked on objects of research directly in a place where an event, state or situation was going on.An instrument or apparatus to gather the data in this research was sheets of observation, in the implementation of the technique of direct observation, an instrument used to take data is sheets of observation of a register of checks ( chek list ) about the supply of and completeness of integrated instrument components media (CII) for science in public primary schools district Siulak Mukai and public primary schools sub district Siulak. As for the media in the observation of completeness is media CII neraca, media CII magnet, media CII pesawat sederhana, media CII cahaya, media CII optik, media CII listrik, media CII bunyi, media CII astronomi, media CII air, media CII panas.

Data which have been collected are presented in the form of table and then it would be of the data analysis .Data analysis technique used is a method of non statistics, namely description data analysis which means of the data collected through research are reported as it was and analyzed descriptilvly to get an overview of the facts. For was used to the sheet observation formulas of the percentage of nana sudjana ( 2011 ):

$$
\mathrm{P}=\frac{\sum X}{N} X 100 \%
$$

$$
\begin{aligned}
& \text { Information : } \mathrm{P}=\text { Percentageg media CII for science } \\
& \begin{aligned}
\sum X & =\text { the number of the media that was available } \\
\mathrm{N} & =\text { the maximum number media } \mathrm{CII} \text { for science }
\end{aligned}
\end{aligned}
$$

\section{Result and discussion}

\subsection{Result}

In accordance with the problems described above, some sort of data collected expressed about complexity integrated instrument components media (CII) for science in primary schools in siulak mukai and primary schools in siulak totaling twelve primary school. The data from the observations are about complexity integrated instrument components media (CII) for science. But before collecting data integrated instrument components media (CII) for science equipment must first be known the availability of integrated instrument components media (CII) for science. The total amount of integrated instrument components 
media (CII) for science available at elementary school Siulak Mukai sub-district is 42 sets, spread over six elementary schools. Furthermore, the total number of integrated instrument components media (CII) for science in elementary school Siulak subdistrict is 37 sets, spread over six elementary schools. Then the complexity of integrated instrument components media (CII) for science in the two subdistricts. the data obtained about the complexity / completeness is analyzed and then displayed in table form as follows.

Table 1. Description Results of integrated instrument components media (CII) for science completeness.

\begin{tabular}{|l|l|l|c|c|}
\hline No & \multicolumn{1}{|c|}{ Media name CII } & Complete & Quite complete & Incomplete \\
\hline 1 & CII neraca & & 4 & 1 \\
\hline 2 & CII magnet & & 1 & 4 \\
\hline 3 & CII pesawat sederhana & & 1 & 3 \\
\hline 4 & CII cahaya & & & 3 \\
\hline 5 & CII optik & & 2 & 6 \\
\hline 6 & CII bunyi & & 2 & 2 \\
\hline 7 & CII listrik & & 2 & 3 \\
\hline 8 & CII astronomi & & 17 & 25 \\
\hline 9 & CII Panas & & & 2 \\
\hline 10 & CII Air & & & 2 \\
\hline Number & & & \\
\hline Average & & & \\
\hline
\end{tabular}

Furthermore, the acquisition of data of integrated instrument components media (CII) for science equipment at elementary school Siulak District, the data obtained in the analysis then displayed in the form of tables as follows.

Table 2. Description Results of integrated instrument components media (CII) for science completeness.

\begin{tabular}{|l|l|c|c|c|}
\hline No & \multicolumn{1}{|c|}{ Media name CII } & Complete & Quite complete & Incomplete \\
\hline 1 & CII neraca & & 4 & 1 \\
\hline 2 & CII magnet & & 1 & 2 \\
\hline 3 & CII pesawat sederhana & 1 & 2 & 2 \\
\hline 4 & CII cahaya & 1 & 1 & 2 \\
\hline 5 & CII optik & 1 & 1 & 1 \\
\hline 6 & CII bunyi & 1 & & \\
\hline 7 & CII listrik & 2 & 1 & \\
\hline
\end{tabular}




\begin{tabular}{|l|l|l|l|l|}
\hline 8 & CII astronomi & & 1 & 3 \\
\hline 9 & CII Panas & 1 & 3 & 1 \\
\hline 10 & CII Air & 2 & 2 & \\
\hline Number & 9 & 16 & 12 \\
\hline Average & & & \\
\hline
\end{tabular}

\subsection{Discussion}

Based on observations about the availability of in integrated instrument components media (CII) for science two district, the availability of integrated instrument components media (CII) for science in public primary schools sub district siulak mukai higher compared with public primary schools sub district siulak. In contrast, for the complexity / completeness of integrated instrument components media (CII) for science elementary school at Siulak sub-district is higher than elementary school at Siulak Mukai sub-district.

10 integrated instrument components media (CII) for science which were observed in 6 primary schools. at Siulak sub-district is available 37 integrated instrument components media (CII) for science $\mathrm{t}$ are located in 6 primary schools 9 integrated instrument components media (CII) for science are complete , 16 integrated instrument components media (CII) for science are quite full and 12 integrated instrument components media (CII) for science are incomplete. While at public primary schools sub district Siulak Mukai 42 are not are complete , 17 integrated instrument components media (CII) for science are quite full and 25 integrated instrument components media (CII) for science are incomplete. integrated instrument components media (CII) 17 science are quite complete and 25 integrated instrument components media (CII) for science not complete. So, public elementary school in sub discrict siulak more allows the success of learning by using integrated instrument components media (CII) for science compared with public elementary school sub discrict Siulak Mukai.

Viewed from the availability of integrated instrument components media (CII) for science, elementary sub districts mukai more than elementary school Siulak but when viewed from the complexity, integrated instrument components media (CII) for science in elementary school Siulak subdistrict more complex / complete from elementary school sub district siulak Mukai. This is because from one CII media observed consists of several components, for example CII balance sheet there are several components in it, among other scales, weighing scales, spring balance etc. At elementary school disctrict Siulak, each integrated instrument components media (CII) for science found to have complete components although not in all schools, while elementary school at district Siulak Mukai in general integrated instrument components media (CII) for science is available but the components are not complete.

\section{Conclusion}

Based on the results of research in obtained, it can be inferred that the availability of integrated instrument components media (CII) for science in public primary schools district Siulak Mukai is higher than that of public elementary school Disrict Siulak but on the whole they allow success of learning using these forms of media . furthermore the complexity / completeness media kits ipa in public primary schools sub discrict siulak is more complete that at public primary schools sub discrict Siulak Mukai. 


\section{References}

A. Siska, R.T. Sari. J.PDN 2, 232 (2017)

Anitah, S, Media Pembelajaran ( LPP UNS, UNS PRESS, 2009)

H. Nawawi, Metode Penelitian Bidang Sosial (Gajah Mada University Press, 2007)

M. Riko. J.PP 2, 6 (2013)

S. Nana, Penilaian Hasil Proses Belajar Mengajar (Remaja Rosdakarya, 2009)

Sugiyono, Metode Penelitian Kuantitatif, Kualitatif dan R \& D ( Alfabeta, 2008)

Sukmadinata, Metode Penelitian Pendidikan. Bandung (Remaja Rosdakarya, 2011)

Umra Hi. A. Ambai,. I. Said,. Ratman. J.KTO 2, 78-79 (2013)

W. Adi. J.S 1, 156 (2011) 